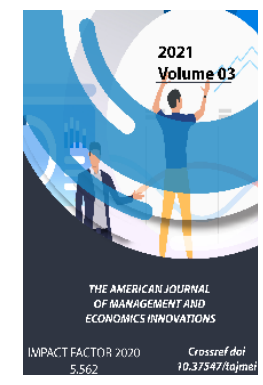

\title{
The Role Of Information Technology In Modern Banks
}

\author{
Shakhlo Shurkrullaevna Davirova \\ Teacher, Tashkent Financial Institute, Tashkent, Uzbekistan \\ Komiljon Shukhrat Ugli Ruziyev \\ Teacher, Tashkent Financial Institute, Tashkent, Uzbekistan
}

Journal Website:

http://theamericanjour

nals.com/index.php/taj

mei

Copyright: Original

content from this work

may be used under the

terms of the creative

commons attributes

4.0 licence.

\section{ABSTRACT}

The article reveals the essence of the concept of "digital innovation", studies the current situation of Internet communications, studies the ways of formation and development of digital banks in Uzbekistan.

\section{KEYWORDS}

Innovation,

digital

bank,

transformation,

ecosystem.

\section{INTRODUCTION}

At the present stage, one of the most important areas of scientific and technological progress is the informatisation of all spheres of human life, based on the large-scale application of computer technology and other electronics that form information and computer systems.In modern banking, banking technologies are becoming increasingly important every day. Uzbekistan pays special attention to the introduction of modern technologies in various industries. The President of the Republic of Uzbekistan, Shavkat Mirziyoyev, expressed his opinion on the state of the banking sector: "Unfortunately, the banking system lags behind modern requirements for 10-15 years, especially in terms of the development of digital technologies, the introduction of new banking products and software. How do we make the economy stable if we have an uncompetitive banking system? Over the past 25 years, we have not paid attention to this area" [1].

The Decree of the President of the Republic of Uzbekistan "On the strategy for reforming the 
banking system of the Republic of Uzbekistan for 2020-2025" approved the Strategy for reforming the banking system of the Republic of Uzbekistan for 2020-2025, the Roadmap for reforming the banking system of the Republic of Uzbekistan, as well as targets for implementing the strategy [2]. This strategy was developed by the Central Bank and the Ministry of Finance in cooperation with the World Bank, taking into account conclusions and recommendations based on the assessment of the current state of the country's banking system, the experience of foreign countries in transforming the financial sector, as well as global trends in the financial sector.

One of the four priorities that deserves particular attention is "Improving the accessibility of banking services," which addresses the people and entrepreneurs' needs, including underserved segments (lowincome individuals, rural populations, small businesses), for basic banking services. Financial accessibility will be ensured by:

- The development and implementation of the National Strategy for Improving Financial Accessibility in cooperation with the World Bank, which sets clear and coordinated directions for improving financial accessibility;

- The concentration of government presence in underserved and vulnerable segments of the population and small businesses;

- Developing an ecosystem of financial intermediation to fill existing gaps.

Banking technologies simplify the process of work of a credit institution in many ways, make it faster and more reliable, establish uniform reporting forms and data provision, and help to create an effective document flow and interaction of bank specialists.

\section{METHODOLOGY}

The importance of information technologies has been a pressing issue for many years. Many large-scale studies have been conducted on this topic around the world, including:

- A report on Digital Intelligence Index (Bhaskar, Ch. et al. 2020);

- Scientific papers on the role of IT in the banking industry (Gabriela, P. \& Georgiana, C. 2011 [4], Rakhi, Sh. \& Ajit, M. 2018 [5], Yefremov, P. \& Vasilyev, I. 2018 [6]);

- A thorough analysis of websites and internet banking of commercial banks (Doniyor, S \& Shakhlo, D. 2015 [7], Shakhlo, D. et al. 2020 [8]).

But in the light of recent changes in the economic and political spheres of Uzbekistan, in particular, with the approval of the Banking Sector Development Strategy, this topic has acquired special relevance.

\section{DISCUSSION}

Information Technology enables sophisticated product development, better market infrastructure, implementation of reliable techniques for control of risks and helps the financial intermediaries to reach geographically distant and diversified markets. The Internet has significantly influenced the delivery channels of banks. The Internet has emerged as an important medium for the delivery of banking products and services.

The Digital Intelligence Index platform is built to encompass several scorecards measuring various aspects of the global digital economy 
[3]. As the foundational measure, the Digital Evolution scorecard tracks the state and historical momentum of 90 economiescomprising $95 \%$ of the world's online population-over twelve years (2008-2019), to provide business and policy guidance for digital growth. The Digital Trust scorecard represents the bridge to "what's next," comparing national outlooks and behaviours around emerging technologies and evaluating the performance of the givers and guarantors of trust across 42 economies. The Digital Evolution scorecard segments the 90 economies in our study into Stand Outs, Stall Outs, Break Outs and Watch Outs. Five economies are particularly notable even within the Stand Out zone: Singapore, Taiwan, Estonia, South Korea, and the UAE. Each has a unique policy-led digital strategy and approaches that are worthy of emulation.

More than most other industries, financial institutions rely on gathering, processing, analyzing, and providing information in order to meet the needs of customers. Given the importance of information in banking, it is not surprising that banks were among the earliest adopters of automated information processing technology.

All banking technologies can be divided into two major categories:

1) Banking technologies for organization of internal work of the bank;

2) Banking technologies for creating channels for working with customers and studying their needs.

The first category is banking technologies, the purpose of which is to optimize the bank's work, organize it and increase the speed of work and efficiency. Such technologies usually include all kinds of automated banking systems. The largest share of processes and transactions in banks is carried out using automated banking systems (ABS).

The automated bank system is the information system intended for the implementation of collection, storage, search, processing and use of information in the sphere of banking activity [1].

One of the most important tasks of information technology is the achievement of business goals. Any IT task should be aimed at obtaining the final result and is associated with the bank's strategy. Only in this case does this activity make sense.

At the moment, many organizations create various automated banking systems designed for almost all areas of business of a commercial bank: from maintaining the bank's operational day to analyzing its activities and making management decisions. The most famous automated banking systems are:

- IABS;

- Temenos Global;

- ABS Globus;

- ASBT.

The main goal of using automated banking systems is to maximize profit and increase the growth rate of the bank. Automated banking systems can act as a means of increasing economic efficiency:

- Through active application of $A B S$ in business processes aimed at increasing the profit of the credit institution;

- Through using ABS as a means of reducing the cost of services provided and optimizing business processes;

- Accelerate customer service through ABS 
- Automation of routine operations using ABS;

With the help of automated banking systems, credit organizations optimize the implementation of traditional banking tasks: accounting, obtaining mandatory reporting, automated cash service for customers, credit and deposit activities and much more.

At the stage of integration of the ABS into the bank system, business processes are optimized, views on the existing mechanism of the bank's work are revised, excess links are removed from the chain of action.

Another advantage of automated banking systems is that they significantly improve the quality of service to bank customers. This aspect is particularly important in today's competitive banking market. Thus, ABS, integrated into the bank's system, can help to build effective business processes, reduce costs and risks associated with customer service.

In addition, there is also a second important group of banking technologies for organizing the internal work of the bank and its business processes, which is aimed at organizing channels for working with customers and studying their needs. This category includes two large areas of banking software development:

1) Remote banking services (Internet banking, mobile banking, etc.);

2) Development of relations with clients and individualization of these relations (MPAs).

A remote banking service is a set of methods for providing banking services to a client without a direct visit to the bank. That is, the remote banking service is a set of services that a client can receive through remote access (mobile phone, Internet, service terminals, etc.).

A special place among the technologies included in remote banking services at the present stage is occupied by mobile banking. Mobile banking facility is an extension of internet banking. Mobile banking is a service provided by a bank or other financial institution that allows its customers to conduct financial transactions remotely using a mobile device. Unlike the related internet banking it uses software, usually called an App, provided by the financial institution for the purpose. Mobile banking is usually available on a 24-hour basis.

Another important area of the development of banking technologies at the present stage is the development of relations with customers and the individualization of these relations (CRM - customer relationship management). CRM technologies provide knowledge of customer requests and needs and allow you to choose the most appropriate ways to service them. This in turn makes the bank's economic activity more active and productive. Customer relationship management enables the bank to generate additional revenue from customer knowledge.

In other words, CRM is a system for working with bank customers throughout the customer's life cycle.

The creation of a CRM system in a bank is due to several goals that a credit institution sets for itself:

- Sales Management

- Improve employee performance

- Organization of customer information 
- Management of the organization's document flow

- Optimization of the interaction of bank's divisions;

- Planning and analysis of the bank's sales.

\section{RESULTS}

The price of the Internet is undoubtedly an integral part of information and, in particular, banking technologies, since it is the adequate cost of access to the Internet that makes it possible to effectively use certain banking products. As an example, consider the comparison of prices for mobile Internet in the CIS countries and, in particular, in Uzbekistan.

Table 1. 2021 1GB Mobile data cost in CIS (former USSR) countries

\begin{tabular}{|c|c|c|c|c|c|c|}
\hline Rank & Name & $\begin{array}{c}\text { Average } \\
\text { price of } \\
\mathbf{1 G B} \text { (local } \\
\text { currency) }\end{array}$ & Currency & $\begin{array}{c}\text { Conversion } \\
\text { rate (USD) } \\
\text { (Frozen } \\
\mathbf{2 3 / 0 3 / 2 0 2 1 )}\end{array}$ & $\begin{array}{c}\text { Average } \\
\text { price of } \\
\mathbf{1 G B} \\
\text { (USD) }\end{array}$ & $\begin{array}{c}\text { Sample } \\
\text { date }\end{array}$ \\
\hline $\mathbf{2}$ & Kyrgyzstan & 12,75 & KGS & 0,01 & $\$ 0,15$ & 10.02 .2021 \\
\hline $\mathbf{6}$ & Russian Federation & 22,06 & RUB & 0,01 & $\$ 0,29$ & 18.02 .2021 \\
\hline $\mathbf{1 3}$ & Belarus & 0,91 & BYR & 0,47 & $\$ 0,43$ & 01.02 .2021 \\
\hline $\mathbf{2 0}$ & Kazakhstan & 249,38 & KZT & 0,00 & $\$ 0,59$ & 10.02 .2021 \\
\hline $\mathbf{2 1}$ & Uzbekistan & 6300,00 & UZS & 0,00 & $\$ 0,60$ & 23.02 .2021 \\
\hline $\mathbf{3 1}$ & Ukraine & 20,83 & UAH & 0,04 & $\$ 0,75$ & 23.02 .2021 \\
\hline $\mathbf{3 5}$ & Armenia & 366,67 & AMD & 0,00 & $\$ 0,76$ & 27.01 .2021 \\
\hline $\mathbf{9 8}$ & Georgia & 6.00 & GEL & 0.30 & $\$ 1.80$ & $05 / 02 / 2021$ \\
\hline $\mathbf{1 0 0}$ & Azerbaijan & 3.10 & AZN & 0.59 & $\$ 1.82$ & $28 / 01 / 2021$ \\
\hline $\mathbf{1 3 2}$ & Tajikistan & 29.75 & TJS & 0.09 & $\$ 2.60$ & $19 / 02 / 2021$ \\
\hline $\mathbf{2 2 3}$ & Turkmenistan & 75.00 & TMT & 0.29 & $\$ 21.41$ & $22 / 02 / 2021$ \\
\hline
\end{tabular}

Uzbekistan ranks 21 among all countries, and 5 among the CIS countries, with a cost of 1 GB of mobile data of 0.6 US dollars. The average annual cost of $1 \mathrm{~GB}$ of mobile data decreased by more than half, from $\$ 3.27$ in 2019 to $\$ 1.34$ in 2020 , which is a positive trend. It is also worth noting that Uzbekistan strengthened its position, rising in the ranking by 33 points in 2021, compared to 2020. In general, the cost of the Internet in Uzbekistan is adequate and creates wide opportunities for the development of technologies by financial institutions and facilitating access to various banking products by consumers.

As it is stated in the Digital Intelligence Index report [3], mobile internet access is necessary but not sufficient for economies with the potential for further digital evolution [3]. Economies in the "Digital South," i.e., those in the BreakOut and Watch Out zones that have not realized the highest levels of digital evolution, would do well to focus on improving access, affordability, and quality of mobile internet and not lose sight of the need 
to invest in more even access to broadband connectivity and better devices to unlock the full potential of digitalization driven economic growth.

Mobile banking is a catalyst for improving the efficiency of the bank. In 2021, the mobile application for the bank is the strongest product, which becomes the main means of both attracting and retaining customers. Every year, the percentage of customers who prefer to use the bank's services through the application increases.

There are special ratings that reflect the opinion of customers about the convenience of banks' applications and their quality. For example, rating by bank.uz, which consists of two stages $[10,11]$. The second stage means a more extensive study of the banking applications according to the concept of "daily banking" and includes more than 80 criteria by which mobile applications of banks were estimated. The criteria are divided into two areas: functionality (120 points) and convenience ( 80 points). The second phase of the study examined the mobile applications of 21 banks. Most of the data were obtained based on application testing by Bank.uz specialists, the missing information was collected from representatives of banks and open sources [12-17].

In general, the banking application market in Uzbekistan is noticeably developing, although not as fast as it could be, given the challenges that the pandemic brought in 2020.

Top- 5 banking applications by the end of 2020 .

1) Apelsin - 140.16 points, Kapital Bank

2) Ipak Yo'liBank - 130.09 points, Ipak Yuli Bank

3) Milliy - 117.76 points, Milliy Bank
4) Zoomrad - 117.16 points, AloqaBank

5) Joyda - 114.72 points, UzPSB

It is important to note that the importance of the convenience of mobile banking and the quality of the application for obtaining banking services is so essential (especially among young people) that most promising customers choose a bank by how convenient its application is.

A modern application that meets all the requirements of customers significantly increases the competitiveness of a credit institution in the banking services market and gives it additional advantages.

The main difficulty of implementing CRM systems in banks is the integration of CRM and other bank systems. Banking technologies implemented in various ways (whether it is remote banking of customers or the use of any other new technologies) require the integration of all systems into a single whole, which ultimately allows the bank to bring new services to the client. The same principle applies to the branches of bank: branch databases must be combined into a single automated banking system. This approach makes it possible to provide the same range of services to all clients.

Consolidation cost of customer information and creating a single database is a very expensive process, however, with the reasonable use of the final result of consolidation, these investments pay off and further make the bank more efficient.

At the moment, no one can deny the importance of CRM in the process of the life of a credit institution and in its development. 
The bank, which does not use these technologies, works more slowly, shows low results and is not fully effective. Therefore, the implementation of CRM systems in banks will continue in the future and will cover an increasing share of credit organizations.

\section{CONCLUSION}

Overall, it is obvious that banking information technologies are a mandatory attribute in the activities of any modern credit institution in the XXI century. All banking technologies (be it automated banking systems, CRM, mobile banking or remote banking in general) help the bank to carry out its activities efficiently and quickly and are reliable means when it comes to the achievement of goals.

ABS help automate the activities of the bank and its business processes, provide information for management decisions and allow you to obtain analytical data on a variety of parameters at any time. Banking technologies aimed at creating channels for working with customers and studying their needs enable the bank to interact more effectively with consumers of their services, study their interest in new products, suggest new solutions as to what can be offered to existing and potential customers.

At the same time, it is difficult to overestimate the significance of any of the described banking technologies separately, because they are created for different purposes and are aimed at different results. However, by coexisting together, these systems greatly increase synergy performance, since the system they form is much more valuable, significant and productive than all these technologies are separate from each other.
Information Technology offers enormous potential and various opportunities to the banking sector. It provides cost-effective, rapid and systematic provision of services to the customer. The efficient use of technology has facilitated accurate and timely management of the increased transaction volumes of banks which comes with the larger customer base.

\section{REFERENCES}

1. Law of the Republic of Uzbekistan About information security in the automated bank system of 04.04.2006, №-30

2. Decree of the President of the Republic of Uzbekistan "On the strategy of reforming the banking system of the Republic of Uzbekistan for 2020-2025" of 12.05.2020, №-5992.

3. Chakravorti, B., Chaturvedi, R. S., Filipovic, C., \& Brewer, G. (2020). Digital in the time of COVID: Trust in the digital economy and its evolution across 90 economies as the planet paused for a pandemic.

4. Cornelia, P. G., \& Georgiana, C. (2011). The Role of Information Technology on the Banking Industry. Ovidius University Annals, Economic Sciences Series, 11(1), 1659-1661.

5. Rakhi, Sharma \& Ajit, Mittal. (2018). Role of IT in Banking Sector \& Challenges. Indian Journal of Economics \& Business. Vol. 17, No. 3, pp. 41-53.

6. Yefremov, P \& Vasilyev, I. (2018). Banking Technologies at Present. Financial Markets and Banks. Vol. 2, pp. 42-48.

7. Doniyor Saidov, Shakhlo Davirova. (2015). Analysis of web sites of commercial banks. Cambridge Journal of Education and Science, 5 (2(14)), 6, pp. 356-359. 
8. Shakhlo Davirova, Stella Arzumanyan, Zokhida Adilova, Nargiza Khujanazarova. (2020). Analysis of the transition to an innovative economy in developed countries (on the example of Israel). International Journal of Advanced Science and Technology, No. 5, (2020), pp. 18041813.

9. Davirova, S., \& Zarefova, A. (2016). The role of internet banking in the banking system of Germany. In International Scientific and Practical Conference World science (Vol. 1, No. 7, pp. 48-49). ROST.

10. Vokhidova, M. K., Davirova, S., Gulyamova, G., Aziz, M., \& Ugli, O. Opportunities for Establishment of Transborder Free Economic Zones in Central Asia. Religación, 4, 235-242.

11. The best mobile applications of banks rating, $2020 . \quad$ URL: https://bank.uz/news/reyting-luchshikhmobilnykh-prilozheniy-v-uzbekistane-poitogam-2020-goda

12. Gabriela, Piciu \& Georgiana, Chipiga. (2011). The Role of Information Technology on the Banking Industry. Ovidius University Annals, Economic Sciences Series. XI. 1659-1661.

13. Rakhi, Sharma \& Ajit, Mittal. (2018). Role of IT in Banking Sector \& Challenges. Indian Journal of Economics \& Business. Vol. 17, No. 3, pp. 41-53.

14. Yefremov, P \& Vasilyev, I. (2018). Banking Technologies at Present. Financial Markets and Banks. Vol. 2, pp. 42-48.

15. Давирова, Ш. Ш., \& Рузиев, К. Ш. У. (2021). Теоретические аспекты суверенного кредитного рейтинга. Scientific progress, 2(1), 815-824.

16. Davirova, S. S. (2017). Credit rating of banks. In International Scientific and
Practical Conference World science (Vol. 3, No. 4, pp. 50-51). ROST. 